\title{
Bud dormancy in apple trees after thermal fluctuations
}

\author{
Rafael Anzanello(1), Flávio Bello Fialho( ${ }^{(2)}$, Henrique Pessoa dos Santos ${ }^{(2)}$, Homero Bergamaschi(3) \\ and Gilmar Arduino Bettio Marodin(3)
}

\begin{abstract}
(1)Fundação Estadual de Pesquisa Agropecuária, RSC-470, Km 170,8, Caixa Postal 44, CEP 95330-000 Veranópolis, RS, Brazil. E-mail: rafael-anzanello@fepagro.rs.gov.br (2)Embrapa Uva e Vinho, Rua Livramento, no 515, Caixa Postal 130, CEP 95700-000 Bento Gonçalves, RS, Brazil. E-mail: flavio.bello@embrapa.br, henrique.p.santos@embrapa.br ${ }^{(3)}$ Universidade Federal do Rio Grande do Sul, Avenida Bento Gonçalves, № 7.712, CEP 91540-000 Porto Alegre, RS, Brazil. E-mail: homerobe@ufrgs.br, marodin@ufrgs.br
\end{abstract}

Abstract - The objective of this work was to evaluate the effect of heat waves on the evolution of bud dormancy, in apple trees with contrasting chilling requirements. Twigs of 'Castel Gala' and 'Royal Gala' were collected in orchards in Papanduva, state of Santa Catarina, Brazil, and were exposed to constant $\left(3^{\circ} \mathrm{C}\right)$ or alternating $(3$ and $15^{\circ} \mathrm{C}$ for $12 / 12$ hours) temperature, combined with zero, one or two days a week at $25^{\circ} \mathrm{C}$. Two additional treatments were evaluated: constant temperature $\left(3^{\circ} \mathrm{C}\right)$, with a heat wave of seven days at $25^{\circ} \mathrm{C}$, in the beginning or in the middle of the experimental period. Periodically, part of the twigs was transferred to $25^{\circ} \mathrm{C}$ for daily budburst evaluation of apical and lateral buds. Endodormancy (dormancy induced by cold) was overcome with less than 330 chilling hours $(\mathrm{CH})$ of constant cold in 'Castel Gala' and less than $618 \mathrm{CH}$ in 'Royal Gala'. A daily $15^{\circ} \mathrm{C}$-temperature cycle did not affect the endodormancy process. Heat waves during endodormancy resulted in an increased $\mathrm{CH}$ to achieve bud requirements. The negative effect of high temperature depended on the lasting of this condition. Chilling was partly cancelled during dormancy when the heat wave lasted 36 continuous hours or more. Therefore, budburst prediction models need adjustments, mainly for regions with mild and irregular winters, such as those of Southern Brazil.

Index terms: Malus domestica, budburst, chilling hours, climate change, dormancy models, endodormancy.

\section{Dormência de gemas em macieira após flutuações térmicas}

Resumo - O objetivo deste trabalho foi avaliar o efeito de ondas de calor sobre a evolução da dormência de gemas de macieiras com necessidades contrastantes de frio hibernal. Brindilas de macieiras 'Castel Gala' e 'Royal Gala' foram coletadas de pomares em Papanduva, SC, e expostas à temperatura constante $\left(3^{\circ} \mathrm{C}\right)$ ou alternada ( 3 e $15^{\circ} \mathrm{C}$, por $12 / 12$ horas), combinadas com zero, um ou dois dias por semana a $25^{\circ} \mathrm{C}$. Dois outros tratamentos foram avaliados: temperatura constante $\left(3^{\circ} \mathrm{C}\right)$, com onda de calor de sete dias a $25^{\circ} \mathrm{C}$, no início ou no meio do período experimental. Periodicamente, parte das brindilas era transferida para $25^{\circ} \mathrm{C}$, para avaliação da brotação das gemas apicais e laterais. A endodormência (dormência induzida pelo frio) foi superada com menos de 330 horas de resfriamento (HF) constante em 'Castel Gala' e menos de 618 HF em 'Royal Gala'. Um ciclo diário de temperatura a $15^{\circ} \mathrm{C}$ não afetou o processo de endodormência. Ondas de calor de $25^{\circ} \mathrm{C}$ durante a endodormência resultaram em aumento de HF para atender à necessidade das gemas. $\mathrm{O}$ efeito negativo da alta temperatura dependeu da duração desta condição. $\mathrm{O}$ resfriamento foi parcialmente anulado durante a dormência, quando a onda de calor durou 36 horas contínuas ou mais. Portanto, os modelos de predição da brotação necessitam de ajustes, principalmente para regiões com invernos amenos e irregulares, como os do Sul do Brasil.

Termos para indexação: Malus domestica, brotação, horas de frio, mudanças climáticas, modelos de dormência, endodormência.

\section{Introduction}

Apple trees need to be exposed to low temperatures during fall and winter, in order to overcome endodormancy (dormancy controlled by chilling) and to start a new growth cycle in the spring (Rohde \& Bhalerao, 2007). If the chilling requirement is not met, delays and irregularities in budburst and flowering occur, affecting fruit production.

The required amount of chilling to overcome endodormancy differs among species and cultivars (Putti et al., 2006; Horvath, 2009). The accumulation of chilling hours $(\mathrm{CH})$ has been related to the sum of hours for plants under conditions below or equal to 
$7.2^{\circ} \mathrm{C}$, a generic temperature for fruit trees (Luedeling \& Brown, 2011). Other models have been used to estimate the amount of chilling required to overcome endodormancy and induce budburst, such as the Utah model (Richardson et al., 1974) and the North Carolina model (Shaltout \& Unrath, 1983), which evaluate the quality of accumulated chill during fall and winter, by attributing different weights to different temperature ranges.

In the climatic conditions of Southern Brazil, there are large temperature fluctuations during the winter period. However, the most common dormancy models were adjusted to North American weather conditions (Luedeling \& Brown, 2011), characterized by relatively regular falls and winters. When used to predict budburst under the conditions of the apple producing regions in Brazil, these models proved to be inaccurate and unreliable (Anzanello et al., 2014). Thus, the importance of heat and cold in the evolution of dormancy should be better understood, in order to adjust or develop best suited models to predict budburst potential.

The importance of dormancy characterization has increased in view of the current and future scenarios of global climate change. Climate models predict a significant reduction of winter chill in the traditional apple producing regions of Brazil (Cardoso et al., 2012). Three possible scenarios predict increases in minimum temperature of $1^{\circ} \mathrm{C}$ (optimistic), $3^{\circ} \mathrm{C}$ (pessimistic), and $5.8^{\circ} \mathrm{C}$ (very pessimistic) in the South of Brazil (Solomon et al., 2007). Biological response models (including dormancy status), adjusted to unstable temperatures during fall and winter, are important to predict scenarios and to minimize impacts of increasing temperatures. Accurate models may be used as decision support tools for orchard management, and to predict adequacy of genotypes to the future climate of a particular region.

Heat waves during dormancy generate anomalies in plants, such as the absence of budburst, or delay and lengthening of the flowering period (Petri \& Leite, 2004). In sprouted and flowered material, anomalies such as shoot growth paralysis, small leaves, and small fruit appear during the vegetative cycle (Petri \& Leite, 2004). Therefore, it is very important to study the effect of heat waves during the winter period, in order to suggest measures to minimize problems of reduced cold or increased temperatures during dormancy.
The objective of this work was to evaluate the effect of heat waves on the evolution of bud dormancy, in apple trees with contrasting chilling requirements.

\section{Materials and Methods}

Dormancy was evaluated in twigs of two apple genotypes, 'Royal Gala' and 'Castel Gala', respectively with medium and low chilling requirements (Denardi \& Seccon, 2005; Petri et al., 2006). Twigs with about $25 \mathrm{~cm}$ length were sampled from a commercial orchard in Papanduva, SC $\left(26^{\circ} 26^{\prime} 68^{\prime \prime} \mathrm{S}, 50^{\circ} 05^{\prime} 47^{\prime \prime} \mathrm{W}\right.$, at $788 \mathrm{~m}$ altitude), in June 2011. Until the collection date, 162 hours of chilling, below or equal to $7.2^{\circ} \mathrm{C}$, were recorded, and plants had already shed their leaves. Seven-year old 'Royal Gala' plants were grafted on rootstock 'Marubakaido' with 'M9' filter, with $1.25 \mathrm{~m}$ between plants and $4.0 \mathrm{~m}$ between rows. Five-year old 'Castel Gala' plants were grafted on 'M9' rootstock, with $0.80 \mathrm{~m}$ between plants and $3.50 \mathrm{~m}$ between rows. The collected material was selected based on bud maturity (fully closed), health (no damage by Grapholita molesta or other causes), and size (approximately $5 \mathrm{~mm}$ diameter). Twigs were wrapped in moist newspaper inside plastic bags and were transported to Embrapa Uva e Vinho, in Bento Gonçalves, RS, Brazil, for bud dormancy evaluation under controlled conditions.

Twigs were cut $20 \mathrm{~cm}$ below the apical bud, retaining approximately 6-10 lateral buds; then, they were cleaned with ethanol at $70 \%$ for $45-60 \mathrm{~s}$ and sodium hypochlorite at $2.5 \%$ for $20 \mathrm{~min}$, and finally they were rinsed thrice with distilled water and dried in the shade for about $30 \mathrm{~min}$. Groups of 20 twigs were packed with black plastic film, vertically set inside incubator chambers Eletrolab EL202 (Eletrolab, São Paulo, SP) in the dark, and subjected to different thermal regimes.

Eight thermal regimes were used with 'Royal Gala': constant $\left(\mathrm{C}=3^{\circ} \mathrm{C}\right)$ or alternating $\left(\mathrm{A}=3\right.$ and $15^{\circ} \mathrm{C}$ for $12 / 12$ hours) temperatures, combined with zero ( $\mathrm{C} 0$ and $\mathrm{A} 0)$, one ( $\mathrm{C} 1$ and $\mathrm{A} 1)$, or two (C2 and $\mathrm{A} 2$ ) days per week at $25^{\circ} \mathrm{C}$, which formed the first six treatments. Two additional regimes were evaluated, with constant temperature $\left(3^{\circ} \mathrm{C}\right)$ and 7 -day heat wave $\left(25^{\circ} \mathrm{C}\right)$ at the beginning $(\mathrm{HB})$ or in the middle (HM) of the experimental period. For 'Castel Gala', only regimes $\mathrm{C} 0, \mathrm{C} 1, \mathrm{C} 2$ and $\mathrm{HB}$ were used, due to the reduced availability of gems and the large number of field 
chilling hours $\left(162 \mathrm{CH}\right.$ below $\left.7.2^{\circ} \mathrm{C}\right)$ at the beginning of the experiment.

After the periods of 330, 426, 522, and 714 chilling hours $\left(\mathrm{CH}\right.$, below $\left.7.2^{\circ} \mathrm{C}\right)$, for 'Castel Gala', and 330, $618,714,810$, and 1,002 CH, for 'Royal Gala' (which included 162 field $\mathrm{CH}$ ), two groups of 20 twigs per combination of cultivar, thermal regime, and chilling hours were transferred to a plant growth chamber Percival Boone model 50036, (Percival Scientific Inc., Perry, IA, USA). The one-centimeter bottom was cut off to unblock vascular bundles, and the twigs were planted upright in moistened phenolic foam $3.75 \mathrm{~cm}$ high. A $1 \times 1 \mathrm{~cm}$ metal mesh was used on the top of the phenolic foam to help the organization and identification of treatments. Temperature in the growth chamber was kept at $25 \pm 1.5^{\circ} \mathrm{C}$, with $70-80 \%$ humidity, and 12-hour photoperiod by day

One additional treatment per cultivar consisted in planting the gems directly in the growth chamber in order to evaluate the budburst, without putting them into the incubator chambers, nor applying any additional thermal regime to them, apart from field chilling hours.

Budburst date of each gem was recorded, and the date when gems reached the green tip stage was noted (Iuchi, 2006), with daily evaluations, for 56 days at $25^{\circ} \mathrm{C}$ in each treatment. Maximum budburst was expressed as a function of the number of chilling hours; the resulting curves were modeled as sigmoids and were compared by the F-test, using the R software (R Development Core Team, 2013).

\section{Results and Discussion}

In the $\mathrm{C} 0$ thermal regime, with $3^{\circ} \mathrm{C}$ constant temperature, less than $618 \mathrm{CH}$ were required to overcome dormancy (budburst larger than 50\%) in 'Royal Gala' apical buds, and less than $330 \mathrm{CH}$, in 'Castel Gala' (Figures $1 \mathrm{~A}$ and $1 \mathrm{C}$ ). These results are compatible with those of Anzanello (2012), who determined the chilling requirements of these two cultivars, under the same conditions, to be about 600 and $300 \mathrm{CH}$, respectively. Moreover, they agree with field results by Denardi \& Seccon (2005) for 'Castel Gala', and Petri et al. (2006) for 'Royal Gala'. The alternating daily temperatures used in regime A0 (3 and $15^{\circ} \mathrm{C}$, in a $12 / 12$-hour cycle) did not affect the chilling requirements of 'Royal Gala', which remained under $618 \mathrm{CH}$ (Figure $1 \mathrm{~A}$ ).

The effect of brief periods of heat $\left(25^{\circ} \mathrm{C}\right)$ on chilling requirements was variable, depending on the thermal regime applied. Under constant temperature $\left(3^{\circ} \mathrm{C}\right)$, the condition of 24 hours per week at $25^{\circ} \mathrm{C}$ (regime $\mathrm{C} 1)$ did not change the chilling requirement. However, 48 hours per week at $25^{\circ} \mathrm{C}$ (regime $\mathrm{C} 2$ ) increased chilling requirements for both cultivars to over $618 \mathrm{CH}$ ('Royal Gala') and over $330 \mathrm{CH}$ ('Castel Gala') (Figures $1 \mathrm{~A}$ and $1 \mathrm{C})$. Under cycling temperatures $\left(3^{\circ} \mathrm{C} / 15^{\circ} \mathrm{C}\right.$ cycle), the exposure of 'Royal Gala' to $25^{\circ} \mathrm{C}$ for 24 (regime A1) and 48 (regime A2) hours per week increased chilling requirements to over $618 \mathrm{CH}$ and over $714 \mathrm{CH}$, respectively (possibly increasing the requirement in about 100 and $200 \mathrm{CH}$, compared to $\mathrm{C} 0$ ). Longer heat waves (regimes HB and HM, with $25^{\circ} \mathrm{C}$ for one week) increased the chilling requirement of both cultivars in more than $96 \mathrm{CH}$ (possibly around $200 \mathrm{CH}$ ), compared to $\mathrm{C} 0$, and also seem to have reduced the maximum budburst.

The statistical analysis of the 'Royal Gala' curves was able to separate three distinct groups (Figure $1 \mathrm{~B}$ ). Thermal regimes $\mathrm{C} 0, \mathrm{~A} 0$ and $\mathrm{C} 1$ formed the first group, requiring less than $618 \mathrm{CH}$ on average to overcome dormancy. The common factor in these three regimes, which differed from the other treatments, was that the heat period never lasted more than 24 hours. The second group consisted of regimes $\mathrm{A} 1$ and $\mathrm{C} 2$, which had heat periods of 36 and 48 hours, respectively (A1 ranged from $3^{\circ} \mathrm{C}$ to $15^{\circ} \mathrm{C}$ for 6 hours, to $25^{\circ} \mathrm{C}$ for 24 hours, and to $15^{\circ} \mathrm{C}$ for 6 hours, before going back to $\left.3^{\circ} \mathrm{C}\right)$. This group differed $(\mathrm{p}=0.0068)$ from the first group, requiring between 618 and $714 \mathrm{CH}$ to overcome dormancy. The third group was formed by regimes A2, $\mathrm{HB}$ and HM, and had heat periods of 60 hours or more. This group's curves differed from the other regimes $(p<0.0001)$ and required over $714 \mathrm{CH}$ to overcome dormancy.

Although 'Castel Gala' curves were not subjected to all the thermal regimes, their statistical analysis also separated the treatments into three groups, in a similar manner to that observed for 'Royal Gala' (Figure 1 D). Treatments $\mathrm{C} 0$ and $\mathrm{C} 1$ were in the first group, with a chilling requirement under $330 \mathrm{CH}$. This group differed $(p=0.04)$ from regime $\mathrm{C} 2$, which had a chilling requirement between 330 and $426 \mathrm{CH}$, and they all 
A
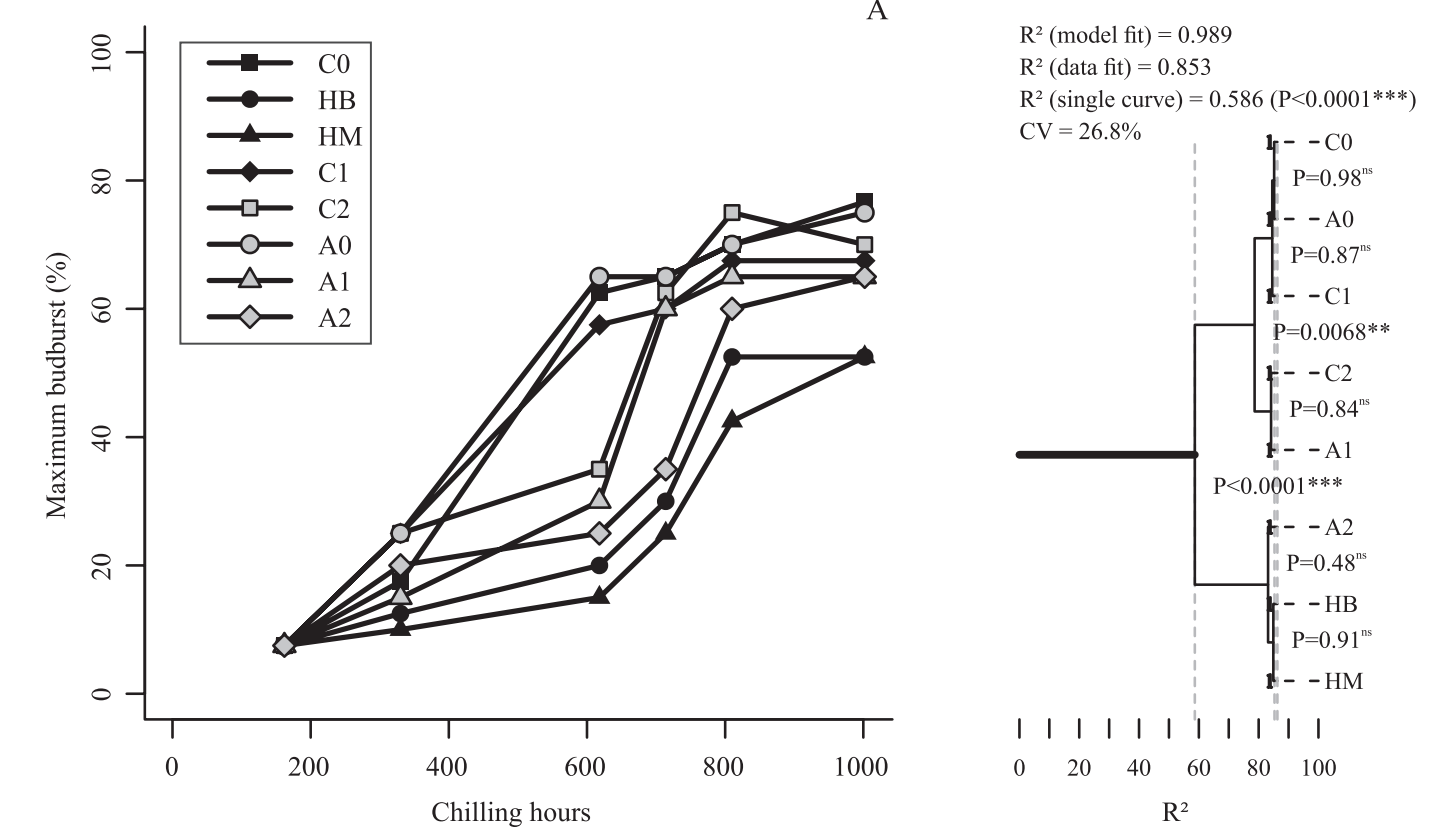

B

$\mathrm{C}$

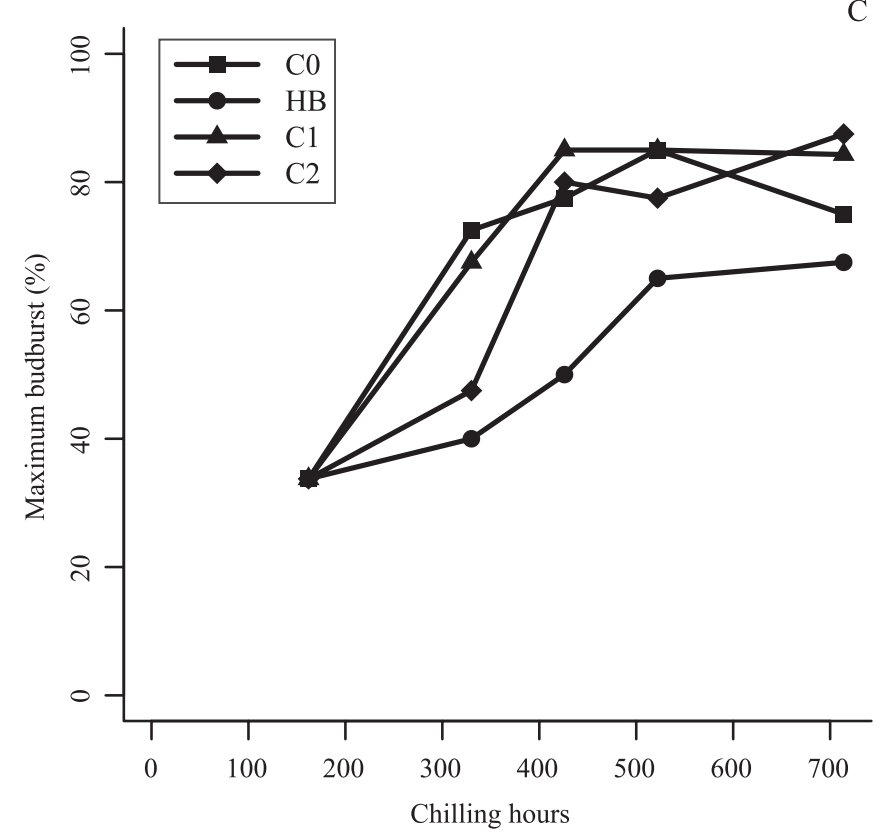
$\mathrm{R}^{2}$ (model fit) $=0.987$
$\mathrm{R}^{2}$ (data fit) $=0.874$
$\mathrm{R}^{2}$ (single curve $)=0.577\left(\mathrm{P}<0.0001^{* * *}\right)$ $\mathrm{CV}=13.2 \%$
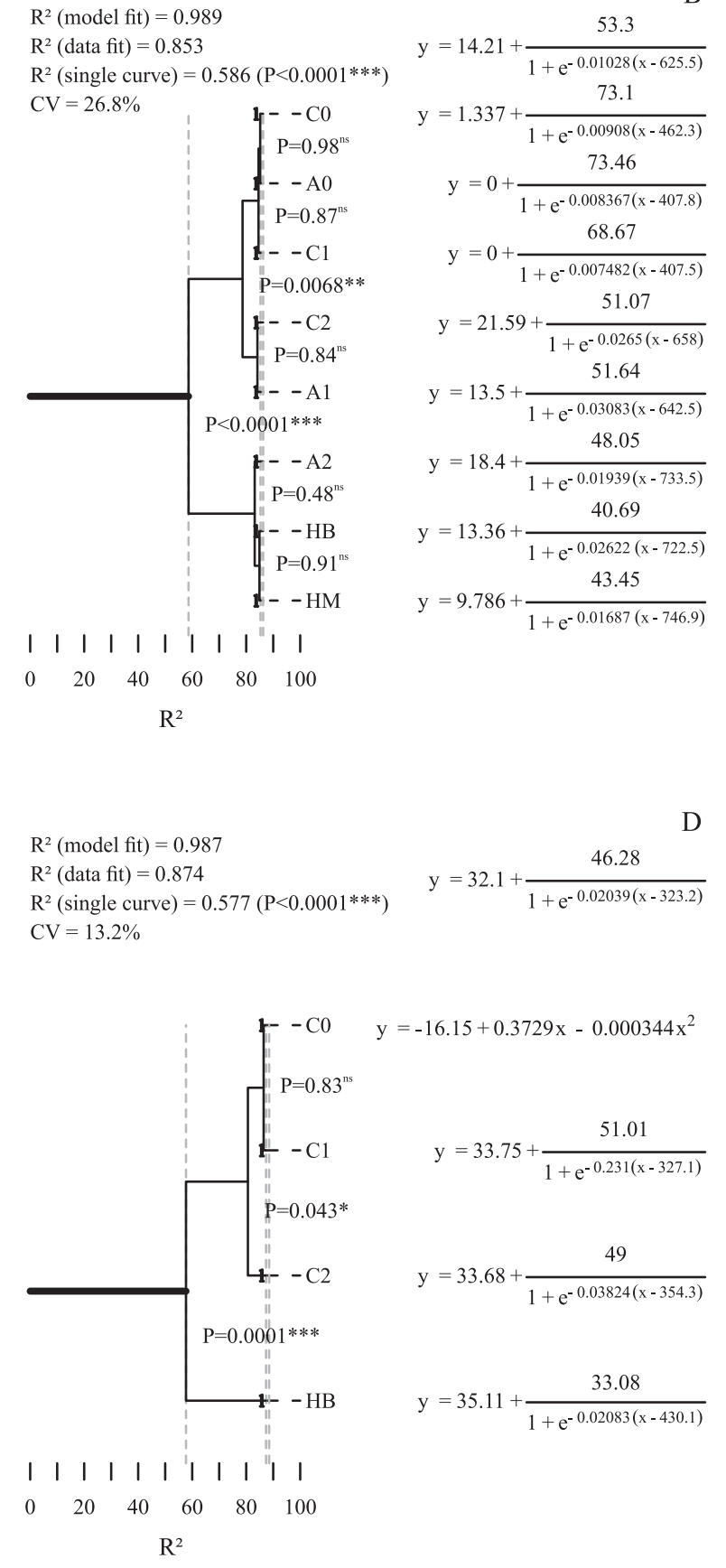

Figure 1. Maximum budburst of apical buds of 'Royal Gala' (A and B) and 'Castel Gala' (C and D) apples at $25^{\circ} \mathrm{C}$, as a function of the number of chilling hours (under $7.2^{\circ} \mathrm{C}$ ) during the dormancy period, under various thermal regimes after 162 chilling hours in the field. Observed values are plotted in $\mathrm{A}$ and $\mathrm{C}$, while a graphical representation of the analysis of variance is shown in $\mathrm{B}$ and $\mathrm{D}$. Thermal regimes were: $\mathrm{C} 0$, constant $3^{\circ} \mathrm{C}$; $\mathrm{C} 1$, weekly cycles of 6 days at $3^{\circ} \mathrm{C}$, and 1 day at $25^{\circ} \mathrm{C} ; \mathrm{C} 2$, weekly cycles of 5 days at $3^{\circ} \mathrm{C}$, and 2 days at $25^{\circ} \mathrm{C}$; A0, alternating daily temperature cycles of $3^{\circ} \mathrm{C}$ for 12 hours, and $15^{\circ} \mathrm{C}$ for 12 hours; A1, alternating daily temperatures $\left(3^{\circ} \mathrm{C} / 15^{\circ} \mathrm{C}\right)$, with 1 day per week at $25^{\circ} \mathrm{C}$; A2, alternating daily temperatures $\left(3^{\circ} \mathrm{C} / 15^{\circ} \mathrm{C}\right)$, with 2 days per week at $25^{\circ} \mathrm{C}$; $\mathrm{HB}$, simulated heat wave of 7 days at $25^{\circ} \mathrm{C}$, at the beginning of the experiment, followed by constant $3^{\circ} \mathrm{C}$; HM, constant $3^{\circ} \mathrm{C}$ for 7 days, followed by a simulated heat wave of 7 days at $25^{\circ} \mathrm{C}$, in the middle of the experimental period, followed by constant $3{ }^{\circ} \mathrm{C}$ thereafter. ${ }^{\text {ns Nonsignificant. }}{ }^{*}, * *$, and ${ }^{* * *}$ Significant at 5,1 , and $0.1 \%$ of probability, respectively. 
differed $(\mathrm{p}=0.0001)$ from regime $\mathrm{HB}$, which required more than $426 \mathrm{CH}$.

A direct relationship between heat duration and budburst capacity was observed for both cultivars (Figures $1 \mathrm{~A}$ and $1 \mathrm{C}$ ). Plants subjected to brief heat periods $\left(1\right.$ or 2 days per week at $25^{\circ} \mathrm{C}$ ) were able to recover their maximum budburst potential. However, longer periods $\left(7\right.$ days at $\left.25^{\circ} \mathrm{C}\right)$ inhibited budburst, even after longer periods of cold.

Alternating warm and cool temperatures can have a synergistic effect, promoting better or faster dormancy overcome, compared to the effect of low temperatures alone, in some apple cultivars (Guak \& Neilsen, 2013). However, high temperatures for long periods during dormancy affect thermal requirements, resulting in irregular budburst (Campoy et al., 2011). For Ruiz et al. (2007), long heat periods increase the chilling requirements of temperate fruit trees. According to Perez et al. (2008) and Chavarria et al. (2009), the regularity and intensity of low temperatures, after dormancy induction, are critical because large temperature fluctuations may increase dormancy duration and result in insufficient and uneven budburst and flowering, thus affecting the production cycle.

Lateral buds were not affected by chilling and remained dormant after the period of heat exposure (Figures $2 \mathrm{~A}$ and $2 \mathrm{C}$ ). This dormancy status is associated mainly to paradormancy, in which lateral budburst is inhibited by apical dominance (Anzanello et al., 2014). Lauri (2007) states that the influence of apical dominance is coordinated by basipetal transport of auxin, which exerts direct inhibition on the growth of axillary buds. For Maguylo et al. (2012), the growth of lateral buds is controlled mainly by paradormancy, rather than by the intrinsic state of endodormancy. Given this effect of apical buds on lateral buds, and the observation that lateral budburst was low for all treatments, the significant differences eventually observed between thermal regimes become unimportant (Figures $2 \mathrm{~B}$ and $2 \mathrm{D}$ ). Maintaining 'Castel Gala' and 'Royal Gala' twigs upright, during the experiment, maximizes the apical dominance (Hawerroth et al., 2013), which justifies the low rates of budburst, even after a long period of exposure to cold.

Maximum requirements of chilling hours varied between 330 and $522 \mathrm{CH}$ for, 'Castel Gala', and between 618 and 1,002 CH, for 'Royal Gala', depending on the thermal regime (Table 1). For Petri et al. (2006) and Campoy et al. (2011), the CH model has not yield satisfactory results because it does not consider the effect of a wider range of temperatures, making it difficult to establish the number of chilling hours required to overcome dormancy in years with unusual temperature regimes. The $\mathrm{CH}$ model is also considered by Luedeling \& Brown (2011) as inadequate to estimate the number of chilling hours to reach budburst because it oversimplifies the biochemical process of dormancy to a simple function of temperature.

The limitations of $\mathrm{CH}$ models resulted in the development of more accurate models, which consider a wider effective temperature range and the negative effects of high temperatures (Luedeling \& Brown, 2011). The chilling unit (CU) models of Utah (Richardson et al. 1974) and North Carolina (Shaltout \& Unrath, 1983) consider high temperatures $\left(25^{\circ} \mathrm{C}\right)$ to have a negative effect of $-1 \mathrm{CU}$ or $-2 \mathrm{CU}$, per hour, respectively. These models have been tested and compared, under different climatic conditions, in cherry (Alburquerque et al., 2008), walnut (Luedeling et al., 2009), apricot (Viti et al., 2010), grapevine (Cortázar-Atauri et al., 2009), and other crops. The Modified Utah and Modified North Carolina models (Ebert et al., 1986) consider that the negative effect occurs only during the first 96 hours of continuous heat. All the four models proved to be inaccurate when the thermal regime included heat waves (Table 1). An ideal model would estimate the same requirement, no matter what thermal regime is used. However, the models did not appear to behave better than the chilling hour method and, in some cases, behaved much worse, as may be verified by the estimates with a negative number of chilling units to overcome dormancy. Chilling unit models, considered effective by some authors (Ebert et al., 1986; Erez, 2000; Legave et al., 2008), appear to be unreliable and mostly inaccurate in the presence of heat waves, and their use is therefore inappropriate in the conditions of Southern Brazil, unless some fundamental change occurs in the modeling process.

Luedeling \& Brown (2011) state that the negative effect of high temperature depends on its intensity and duration. This was initially reported by Erez \& Lavee 

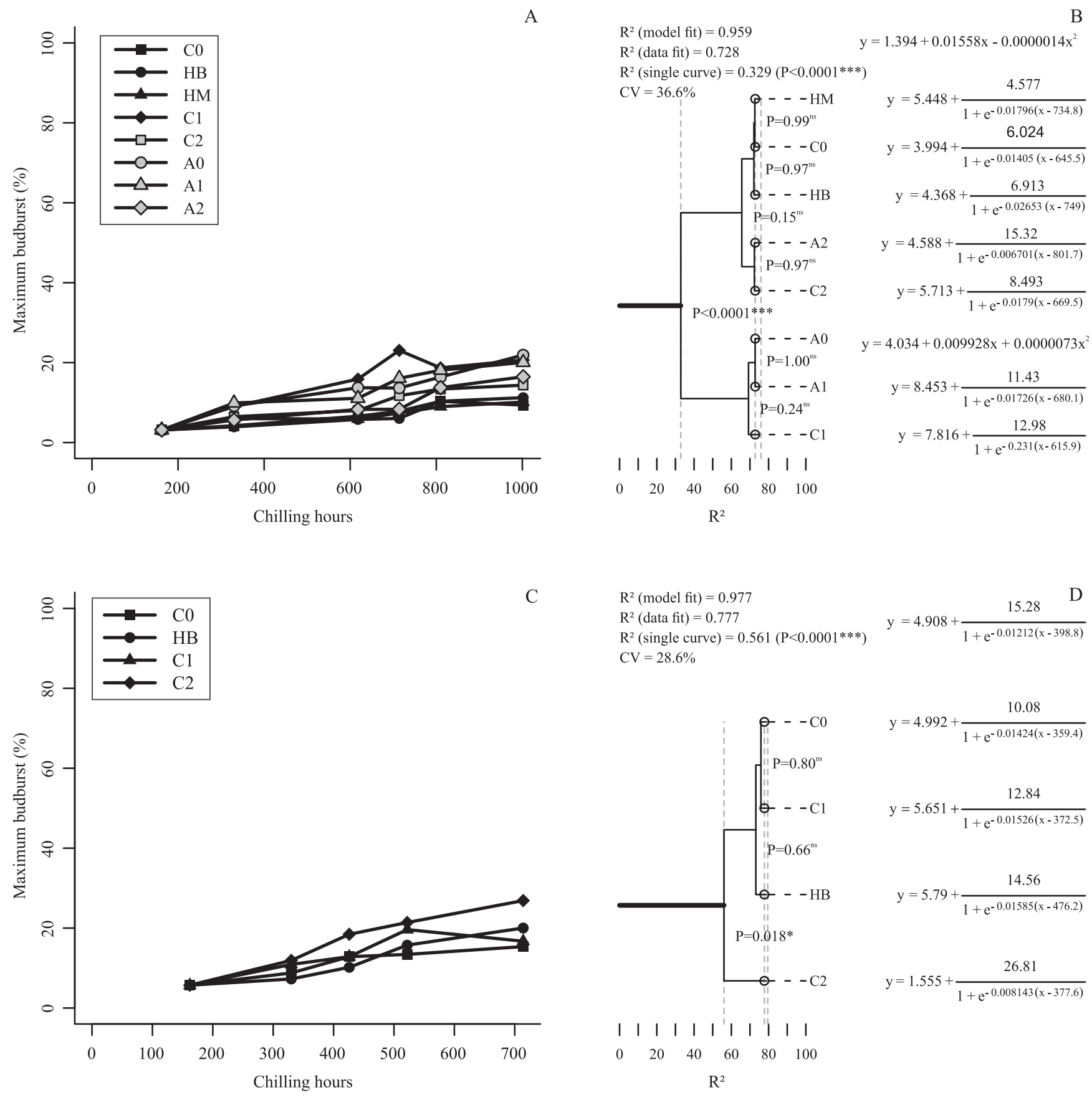

Figure 2. Maximum budburst of lateral buds of 'Royal Gala' (A and B) and 'Castel Gala' apples (C and D) at $25^{\circ} \mathrm{C}$, as a function of the number of chilling hours (under $7.2^{\circ} \mathrm{C}$ ) during the dormancy period, under various thermal regimes after 162 chilling hours in the field. Observed values are plotted in $\mathrm{A}$ and $\mathrm{C}$, while a graphical representation of the analysis of variance is shown in $\mathrm{B}$ and $\mathrm{D}$. Thermal regimes were: $\mathrm{C} 0$, constant $3^{\circ} \mathrm{C} ; \mathrm{C} 1$, weekly cycles of 6 days at $3^{\circ} \mathrm{C}$, and 1 day at $25^{\circ} \mathrm{C} ; \mathrm{C} 2$, weekly cycles of 5 days at $3^{\circ} \mathrm{C}$, and 2 days at $25^{\circ} \mathrm{C}$; A0, alternating daily temperature cycles of $3^{\circ} \mathrm{C}$ for 12 hours, and $15^{\circ} \mathrm{C}$ for 12 hours; $\mathrm{A} 1$, alternating daily temperatures $\left(3^{\circ} \mathrm{C} / 15^{\circ} \mathrm{C}\right)$, with 1 day per week at $25^{\circ} \mathrm{C}$; $\mathrm{A} 2$, alternating daily temperatures $\left(3^{\circ} \mathrm{C} / 15^{\circ} \mathrm{C}\right)$, with 2 days per week at $25^{\circ} \mathrm{C}$; $\mathrm{HB}$, simulated heat wave of 7 days at $25^{\circ} \mathrm{C}$, at the beginning of the experiment, followed by constant $3^{\circ} \mathrm{C}$; HM, constant $3^{\circ} \mathrm{C}$ for 7 days, followed by a simulated heat wave of 7 days at $25^{\circ} \mathrm{C}$, in the middle of the experimental period, followed by constant $3^{\circ} \mathrm{C}$ thereafter. ${ }^{n}$ Nonsignificant. $*$, **, and $* * *$ Significant at 5,1 , and $0.1 \%$ of probability, respectively. 
(1971), who claimed that only after 8 hours of exposure to $21^{\circ} \mathrm{C}$ the effect of chilling hours on dormancy was partially cancelled. They also sustain that, at higher temperatures $\left(24^{\circ} \mathrm{C}\right)$, a mere 2 hours of exposure might cancel chilling hours. The present study suggests that only after 24 to 36 hours does heat cancel part of the effect of accumulated chilling. In the alternating temperature regimes, 24 or 48 hours at $25^{\circ} \mathrm{C}$ were always accompanied by 12 hours at $15^{\circ} \mathrm{C}$, totaling 36 or 60 hours of absence of chilling. These conditions reversed the process of dormancy and increased the chilling requirement of the cultivars (Figures $1 \mathrm{~A}$ and $1 \mathrm{C}$ ), reinforcing the need for adjustments in the usual dormancy models. Models should partially cancel the effect of chilling only after over 24 hours of heat, with the dormancy process being immune to the influence of high temperatures in the period of a single day. One of the main deficiencies of current dormancy models is that they fail to adequately estimate cold requirements under heat wave conditions, such as the ones tested in the present work.

Table 1. Maximum chilling units required for overcoming dormancy, as estimated by the number of chilling hours $(\mathrm{CH})$ under $7.2^{\circ} \mathrm{C}$, Utah (UT), North Carolina (NC), Modified Utah (UTm), and Modified North Carolina (NCm) models, for 'Royal Gala' (G) and 'Castel Gala' (K) apples.

\begin{tabular}{lcccccc}
\hline \multicolumn{2}{l}{ Treatment $^{(1)}$ Cultivar } & \multicolumn{5}{c}{ Models } \\
\cline { 3 - 7 } & & $\mathrm{CH}<7.2^{\circ} \mathrm{C}$ & $\mathrm{UT}$ & $\mathrm{NC}$ & $\mathrm{UTm}$ & $\mathrm{NCm}$ \\
\hline $\mathrm{C} 0$ & $\mathrm{~K}$ & 330 & 330 & 330 & 330 & 330 \\
$\mathrm{C} 0$ & $\mathrm{G}$ & 618 & 618 & 618 & 618 & 618 \\
$\mathrm{~A} 0$ & $\mathrm{G}$ & 618 & 618 & 618 & 618 & 618 \\
\hline $\mathrm{C} 1$ & $\mathrm{~K}$ & 330 & 306 & 283 & 306 & 283 \\
$\mathrm{C} 2$ & $\mathrm{~K}$ & 426 & 330 & 234 & 330 & 234 \\
$\mathrm{HB}$ & $\mathrm{K}$ & 522 & 354 & 186 & 450 & 378 \\
$\mathrm{C} 1$ & $\mathrm{G}$ & 618 & 546 & 474 & 546 & 474 \\
$\mathrm{C} 2$ & $\mathrm{G}$ & 714 & 474 & 234 & 474 & 234 \\
$\mathrm{~A} 1$ & $\mathrm{G}$ & 714 & 522 & 330 & 522 & 330 \\
$\mathrm{~A} 2$ & $\mathrm{G}$ & 810 & 282 & -246 & 282 & -246 \\
$\mathrm{HB}$ & $\mathrm{G}$ & 810 & 642 & 474 & 738 & 666 \\
$\mathrm{HM}$ & $\mathrm{G}$ & 1002 & 834 & 666 & 930 & 858 \\
\hline
\end{tabular}

${ }^{(1)} \mathrm{C} 0$, constant $3^{\circ} \mathrm{C} ; \mathrm{C} 1$, weekly cycles of 6 days at $3^{\circ} \mathrm{C}$, and 1 day at $25^{\circ} \mathrm{C}$; $\mathrm{C} 2$, weekly cycles of 5 days at $3^{\circ} \mathrm{C}$, and 2 days at $25^{\circ} \mathrm{C}$; A0, alternating daily temperature cycles of $3^{\circ} \mathrm{C}$ for 12 hours, and $15^{\circ} \mathrm{C}$ for 12 hours; $\mathrm{A} 1$, alternating daily temperatures $\left(3^{\circ} \mathrm{C} / 15^{\circ} \mathrm{C}\right)$, with 1 day per week at $25^{\circ} \mathrm{C}$; $\mathrm{A} 2$, alternating daily temperatures $\left(3^{\circ} \mathrm{C} / 15^{\circ} \mathrm{C}\right)$, with 2 days per week at $25^{\circ} \mathrm{C}$; $\mathrm{HB}$, simulated heat wave of 7 days at $25^{\circ} \mathrm{C}$, at the beginning of the experiment, followed by constant $3{ }^{\circ} \mathrm{C}$; HM, constant $3{ }^{\circ} \mathrm{C}$ for 7 days, followed by a simulated heat wave of 7 days at $25^{\circ} \mathrm{C}$ in the middle of the experimental period, followed by constant $3^{\circ} \mathrm{C}$ thereafter.

\section{Conclusions}

1. Daily temperature cycles ranging from $3^{\circ} \mathrm{C}$ to $15^{\circ} \mathrm{C}$ do not affect the process of overcoming endodormancy.

2. Heat waves of $25^{\circ} \mathrm{C}$ during dormancy result in an increase in the number of the necessary chilling hours to achieve the chilling requirements of apple buds.

3 . The negative effect of high temperature depends on its duration, and heat partially cancels chilling during dormancy only if it lasts 36 or more hours.

\section{References}

ALBURQUERQUE, N.; GARCÍA-MONTIEL, F.; CARRILLO, A.; BURGOS, L. Chilling and heat requirements of sweet cherry cultivars and the relationship between altitude and the probability of satisfying the chill requirements. Environmental and Experimental Botany, v.64, p.162-170, 2008. DOI: 10.1016/j. envexpbot.2008.01.003.

ANZANELLO, R. Fisiologia e modelagem da dormência de gemas em macieira. 2012. 281p. Tese (Doutorado) - Universidade Federal do Rio Grande do Sul, Porto Alegre.

ANZANELLO, R.; FIALHO, F.B.; SANTOS, H.P. dos; BERGAMASCHI, H.; MARODIN, G.A.B. Métodos biológicos para avaliar a brotação de gemas em macieira para modelagem da dormência. Semina: Ciências Agrárias, v.35, p.1173-1185, 2014.

CAMPOY, J.A.; RUIZ, D.; EGEA, J. Dormancy in temperate fruit trees in a global warming context: a review. Scientia Horticulturae, v.130, p.357-372, 2011. DOI: 10.1016/j.scienta.2011.07.011.

CARDOSO, L.S.; BERGAMASCHI, H.; BOSCO, L.C.; PAULA, V.A. de; MARODIN, G.A.B.; CASAMALI, B.; NACHTIGALL, G.R. Disponibilidades climáticas para macieira na região de Vacaria, RS. Ciência Rural, v.42, p.1960-1967, 2012. DOI: 10.1590/S0103-84782012005000097.

CHAVARRIA, G.; HERTER, F.G.; RASEIRA, M. do C.B.; RODRIGUES, A.C.; REISSER, C.; SILVA, J.B. da. Mild temperatures on bud breaking dormancy in peaches. Ciência Rural, v.39, p.2.016-2.021, 2009. DOI: 10.1590/ S0103-84782009000700010.

CORTÁZAR-ATAURI, I.C.; BRISSON, N.; GAUDILLERE, J.P. Performance of several models for predicting budburst date of grapevine (Vitis vinifera L.) International Journal of Biometeorology, v.53, p.317-326, 2009. DOI: 10.1007/ s00484-009-0217-4.

DENARDI, F.; SECCON, J.J. 'Castel Gala' - mutação da macieira 'Gala' com baixa necessidade de frio e maturação precoce. Agropecuária Catarinense, v.18, p.78-82, 2005.

EBERT, A.; PETRI, J.L.; BENDER, R.J.; BRAGA, H.J. First experiences with chill-unit models in Southern Brazil: modelling in fruit research. Acta Horticulturae, n.184, p.74-86, 1986.

EREZ, A. Bud dormancy: a suggestion for the control mechanism and its evolution. In: VIÉMONT, J.-D.; CRABBÉ, J. (Ed.). 
Dormancy in plants: from whole plant behaviour to cellular control. Wallingford: CAB International, 2000. p.23-33.

EREZ, A.; LAVEE, S. The effect of climatic conditions on dormancy development of peach buds. Journal of the American Society for Horticultural Science, v.96, p.711-714, 1971.

GUAK, S.; NEILSEN, D. Chill unit models for predicting dormancy completion of floral buds in apple and sweet cherry. Horticulture Environment and Biotechnology, v.54, p.29-36. 2013. DOI: $10.1007 / \mathrm{s} 13580-013-0140-9$.

HAWERROTH, F.J.; HERTER, F.G.; PETRI, J.L.; MARAFON, A.C.; LEONETTI, J.F. Evaluation of winter temperatures on apple budbreak using grafted twigs. Revista Brasileira de Fruticultura, v.35, p.713-721, 2013. DOI: 10.1590/S0100-29452013000300007.

HORVATH, D. Common mechanisms regulate flowering and dormancy. Plant Science, v.177, p.523-531, 2009. DOI: 10.1016/j. plantsci.2009.09.002.

IUCHI, V.L. Botânica e fisiologia. In: A CULTURA da macieira. Florianópolis: Epagri, 2006. p.59-104.

LAURI, P.-E. Differentiation and growth traits associated with acrotony in the apple tree (Malus domestica, Rosaceae). American Journal of Botany, v.94, p.1273-1281, 2007. DOI: 10.3732/ ajb.94.8.1273.

LEGAVE, J.M.; FARRERA, I.; ALMERAS, T.; SANTAMARIA, P.; CALLEJA, M. Selecting models of apple flowering time and understanding how global warming has had an impact on this trait. Journal of Horticultural Science and Biotechnology, v.83, p.76-84, 2008.

LUEDELING, E.; BROWN, P.H. A global analysis of the comparability of winter chill models for fruit and nut trees. International Journal of Biometeorology, v.55, p.411-421, 2011. DOI: $10.1007 / \mathrm{s} 00484-010-0352-y$.

LUEDELING, E.; ZHANG, M.H.; MCGRANAHAN, G.; LESLIE, C. Validation of winter chill models using historic records of walnut phenology. Agricultural and Forest Meteorology, v.149, p.1854-1864, 2009. DOI: 10.1016/j.agrformet.2009.06.013.

MAGUYLO, K.; COOK, N.C.; THERON, K.I. Environment and position of first bud to break on apple shoots affects lateral outgrowth. Trees, v.26, p.663-675, 2012. DOI: 10.1007/ s00468-011-0634-y.

PEREZ, F.J.; ORMENO, N.J.; REYNAERT, B.; RUBIO, S. Use of the dynamic model for the assessment of winter chilling in a temperate and a subtropical climatic zone of Chile. Chilean Journal of Agricultural Research, v.68, p.198-206, 2008. DOI: 10.4067/S0718-58392008000200010.

PETRI, J.L.; LEITE, G.B. Consequences of insufficient winter chilling on apple tree budbreak. Acta Horticulturae, n.662, p.53-60, 2004.

PETRI, J.L.; PALLADINI, L.A.; POLA, A.C. Dormência e indução da brotação da macieira. In: A CULTURA da macieira. Florianópolis: Epagri, 2006. p.261-298.

PUTTI, G.L.; PETRI, J.L.; MENDEZ, M.H.; LEITE, G.B. Necessidades térmicas para indução da brotação de diferentes cultivares de macieira. Agropecuária Catarinense, v.19, p.71-74, 2006.

R DEVELOPMENT CORE TEAM. R: a language and environment for statistical computing. Vienna: R Foundation for Statistical Computing, 2012.

RICHARDSON, E.A.; SEELEY, S.D.; WALKER, D.R. A model for estimating the completion of rest for 'Redhaven' and 'Elberta' peach trees. HortScience, v.1, p.331-332, 1974.

ROHDE, A.; BHALERAO, R.P. Plant dormancy in the perennial context. Trends in Plant Science, v.12, p.217-223, 2007. DOI: 10.1016/j.tplants.2007.03.012.

RUIZ, D.; CAMPOY, J.A.; EGEA, J. Chilling and heat requirements of apricot cultivars for flowering. Environmental and Experimental Botany, v.61, p.254-263, 2007. DOI: 10.1016/j. envexpbot.2007.06.008.

SHALTOUT, A.D.; UNRATH, C.R. Rest completion prediction model for 'Starkrimson Delicious' apples. Journal of the American Society for Horticultural Science, v.108, p.957-961, 1983.

SOLOMON, S.; QIN, D.; MANNING, M.; CHEN, Z.; MARQUIS, M.; AVERYT, K.B.; TIGNOR, M.; MILLER, H.L. (Ed.). Climate change 2007 - the physical science - contribution of Working Group I to the Fourth Assessment Report of the Intergovernmental Panel on Climate Change. Cambridge: Cambridge University Press, 2007. 996p.

VITI, R.; ANDREINI, L.; RUIZ, D.; EGEA, J.; BARTOLINI, S.; IACONA, C.; CAMPOY, J.A. Effect of climatic conditions on the overcoming of dormancy in apricot flower buds in two Mediterranean areas: Murcia (Spain) and Tuscany (Italy). Scientia Horticulturae, v.124, p.217-224, 2010. DOI: 10.1016/j. scienta.2010.01.001.

Received on February 25, 2014 and accepted on May 26, 2014

Pesq. agropec. bras., Brasília, v.49, n.6, p.457-464, jun. 2014

DOI: $10.1590 / \mathrm{S} 0100-204 X 2014000600007$ 